\title{
PENERAPAN MODEL PEMBELAJARAN FLIPPED CLASSROOM DAN COURSE REVIEW HORAY BERBASIS LESSON STUDY UNTUK MENINGKATKAN AKTIVITAS DAN HASIL BELAJAR SISWA PADA MATA PELAJARAN EKONOMI DI KELAS XI IPS 2 MAN KOTA BATU
}

\author{
Arfiyanti Agustiningrum ${ }^{1}$, Agung Haryono² \\ 1. Economic Education Program, Faculty of Economics, State University Malang \\ 2. Economic Education Program, Faculty of Economics, State University Malang \\ agustiningrumarfiyanti@ymail.com, agung.haryono.fe@um.ac.id
}

\begin{abstract}
This research aims to increase the activity and student learning outcomes in Social Eleventh Graders at 2 MAN Batu by implementing Flipped Classroom and Course Review Horray (CRH) learning model based lesson study. This research consisted of two cycles. Data were collected through documentation, observation, field notes, and tests. Qualitative descriptive tehnique was employed for analyzing the data. The results of student learning activities in the first cycle was 58 and the second cycle the stucdent learning activities value increased to 72 . The research result of students learning outcomes in the first cycle was $75,00 \%$ and the second cycle increased to $89,29 \%$.
\end{abstract}

Keywords: Flipped Classroom, Course Review Horray (CRH), Lesson Study, Learning Activities, Learning Outcomes of Economics

History of Article:

Received:(02 July 2017), Accepted : (19 September 2017), Publised: (15 October 2017)

\section{Citation:}

Agustiningrum, Arfiyanti \& Agung Haryono (2017) Penerapan Model Pembelajaran Flipped Classroom Dan Course Review Horay Berbasis Lesson Study Untuk Meningkatkan Aktivitas Dan Hasil Belajar Siswa Pada Mata Pelajaran Ekonomi Di Kelas XI Ips 2 Man Kota Batu [Application of Learning model flipped classroom and course review horay based on lesson study to improve student activity and Student Results Of Class XI IPS 2 On Economic Subject At MAN Kota Batu]. Jurnal Pendidikan Ekonomi, 10(2), 111-120.

(C) Universitas Negeri Malang 


\section{PENDAHULUAN}

Ekonomi adalah ilmu sosial yang bersifat dinamis. Namun dalam kenyataannya materi ekonomi kurang terakomodasi dengan baik dikelas. Kondisi ini berpengaruh pada hasil belajar siswa sehingga hasil belajar siswa menjadi rendah. Data hasil belajar siswa di kelas XI IPS 2 MAN Kota Batu yaitu persentase ketuntasan belajar siswa yaitu 62,50\% dimana terdapat 15 siswa yang berhasil mendapat nilai sesuai atau melebihi KKM yang ditentukan sekolah, sedangkan 13 siswa yang lain atau sebesar 37,50\% siswa nilai yang diperoleh masih dibawah KKM.

Selain itu faktor lain yang kurang mendukung kegiatan pem-belajaran adalah kurangnya kesiapan siswa. Menurut Jamies Drever (dalam Slameto: 2003) salah satu faktor yang mempengaruhi siswa dalam belajar adalah kesiapan atau readiness. Kesiapan yang dimiliki dalam pembelajaran akan membuat siswa memberikan suatu respon atau reaksi atas informasi yang diterimanya. Jika siswa memasuki kelas tanpa adanya kesiapan maka siswa akan pasif didalam proses pembelajaran. Informasi akan diterima secara langsung tanpa ada respon aktif berupa pendapat, pertanyaan atau sanggahan dari siswa. Hal ini berpengaruh pada aktivitas belajar siswa. Di kelas XI IPS 2 MAN Kota Batu, nilai rata-rata aktivitas belajar siswa yaitu 63 dengan nilai KKM sebesar 75 .

Salah satu cara yang dapat dilakukan guru adalah dengan mengubah model pembelajaran. Model pembelajaran yang dapat diterapkan adalah model pembelajaran flipped classroom. Model pembelajaran flipped classroom adalah model pembelajaran yang membalik model pembelajaran tradisional, dimana materi diberikan didalam kelas dan siswa mengerjakan tugas dirumah melalui video pembelajaran. Mempelajari materi sebelum kelas dimulai dapat dijadikan pengetahuan dasar bagi siswa atau priming. Sebuah penelitian tentang efek priming pada memori menunjukkan bahwa ketika siswa mendapat rangsangan tertentu, misalnya satu fakta, memori atau ingatan mereka akan menghubungkan pengalaman mereka sebelumnya (priming) yang berhubungan dengan rangsangan (Bodie dkk, 2006).

Berdasarkan modul dalam makalah yang berjudul The Implementing a Flipped Classroom: An Instructional Module (Shimamoto: 2012) bahwa penerapan model pembelajaran Flipped Classroom dapat dikolaborasikan dengan berbagai kegiatan salah satunya adalah competitive games. Permainan secara individual atau kelompok mampu meningkatkan rasa kompetitif dan mengukur tingkat pemahaman yang dimiliki siswa. Salah satu model pembelajaran yang bisa diterapkan adalah model pembelajaran course review horray. Melalui penerapan course review horray siswa dapat melihat efektivitas kelompok masing-masing. Berdasarkan artikel dalam jurnal yang ditulis oleh Burke (2011), bahwa jika pekerjaan dilakukan secara berkelompok maka mereka harus mampu mengetahui efektivitas kelompoknya.

Penelitian ini bertujuan untuk mengatasi masalah belajar siswa tetapi dalam prosesnya tidak secara keseluruhan hanya berhubungan dengan siswa. Berdasarkan jurnal yang ditulis oleh Gómez dkk (2015) bahwa pembelajaran tidak hanya cara belajar siswa melainkan pengembangan profesionalitas guru. Oleh karena itu penelitian lebih baik jika pelaksanaan pembelajaran dilakukan berbasis Lesson Study. Hal ini akan memberikan kemudahan bagi guru untuk mengamati perkembangan aktivitas siswa secara rinci. Dengan begitu guru akan lebih mudah mengukur dan melihat pembelajaran yang dilakukan di dalam kelas.

Melalui penelitian ini akan diketahui (1) Bagaimana penerapan model pembelajaran flipped classroom dan model pembelajaran course review horay berbasis Lesson Study pada mata pelajaran Ekonomi di kelas XI IPS 2 MAN Kota Batu; (2) Apakah penerapan model pembelajaran flipped classroom dan model pembelajaran course review horay 
berbasis Lesson Study pada mata pelajaran Ekonomi di kelas XI IPS 2 MAN Kota Batu mampu meningkatkan aktivitas belajar siswa; (3) Apakah penerapan model pembelajaran flipped classroom dan model pembelajaran course review horay berbasis Lesson Study pada pada mata pelajaran Ekonomi di kelas XI IPS 2 MAN Kota Batu mampu meningkatkan hasil belajar siswa. Sehingga akan bermanfaat bagi (1) Guru, sebagai pertimbangan model pembelajaran dalam mata pelajaran ekonomi dikelas untuk mengatasi masalah rendahnya aktivitas dan hasil belajar siswa; (2) Peneliti, Dapat digunakan sebagai pengalaman dalam merancang model pembelajaran flipped classroom dan model pembelajaran course review horay berbasis Lesson Study untuk memecahkan masalah pembelajaran dikelas, khususnya rendahnya aktivitas dan hasil belajar siswa; (3) Peneliti selanjutnya, sebagai referensi dan bahan pertimbangan untuk melakukan kegiatan penelitian mengenai penerapan model pembelajaran flipped classroom dan model pembelajaran course review horay berbasis Lesson Study untuk meningkatkan aktivitas dan hasil belajar siswa dikemudian hari.

\section{METODE PENELIITIAN}

Kehadiran peneliti dalam pene-litian tindakan kelas ini dilakukan secara penuh. Penelitian dilakukan tanpa adanya perwakilan dan peneliti tidak diperkenankan meninggalkan tempat penelitian selama penelitian berlangsung. Kehadiran peneliti sebagai pengamat, perencana dan pelaksana tindakan, pengumpulan data serta melaporkan hasil penelitian.

Subjek dalam penelitian ini adalah siswa kelas XI IPS 2 MAN Kota Batu dengan nilai rata-rata kelas 74 yang berarti masih belum bisa mencapai di KKM yaitu 75 . Pada penelitian ini ada beberapa data yang diambil oleh peneliti selama penelitian berlangsung. Jenis-jenis data, sumber data dan teknik pengumpulan data yang diperoleh peneliti dapat dilihat dalam tabel berikut ini.

\begin{tabular}{|c|c|c|c|}
\hline No. & Data & Sumber Data & Teknik pengumpulan \\
\hline 1. & Daftar nama siswa kelas XI IPS 2 & $\begin{array}{l}\text { Guru ekonomi } \\
\text { kelas XI IPS } 2\end{array}$ & Dokumentasi \\
\hline 2. & $\begin{array}{l}\text { Nilai siswa sebelum diadakannya } \\
\text { tindakan }\end{array}$ & $\begin{array}{l}\text { Guru ekonomi } \\
\text { kelas XI IPS } 2\end{array}$ & Dokumentasi \\
\hline 3. & Nilai siswa tugas kelompok & Siswa & Tes tulis (kelompok) \\
\hline 4. & Nilai tes akhir siklus & Siswa & Tes Tulis (individu) \\
\hline 5. & Data aktivitas siswa & Siswa & $\begin{array}{l}\text { Observasi, catatan } \\
\text { lapangan }\end{array}$ \\
\hline 6. & Pelaksanaan lesson study & $\begin{array}{l}\text { Guru model, } \\
\text { siswa, tim } \\
\text { lesson study }\end{array}$ & Observasi \\
\hline 7. & $\begin{array}{l}\text { Keterlaksanaan model } \\
\text { pembelajaran }\end{array}$ & Guru model & Observasi \\
\hline
\end{tabular}




\section{HASIL DAN PEMBAHASAN}

Perbandingan Ketuntasan Hasil Belajar Siswa Ranah Kognitif Siklus 1

\begin{tabular}{lccccc}
\hline \multirow{1}{*}{ Hasil Belajar } & \multicolumn{3}{c}{ Ketuntasan belajar } & \multirow{2}{*}{ Keterangan } \\
\cline { 2 - 4 } & Jumlah siswa & Persentase (\%) & \\
\cline { 2 - 4 } & Tuntas & Belum & Tuntas & Belum \\
Tuntas & & Tuntas & \\
\hline Sebelum penerapan & 15 & 13 & $62,50 \%$ & $37,50 \%$ & \multirow{2}{*}{ Meningkat } \\
Siklus I & 21 & 7 & $75,00 \%$ & $25,00 \%$ & \\
Siklus II & 25 & 3 & $89,29 \%$ & $10,71 \%$ & \\
\hline
\end{tabular}

Nilai aktivitas siswa Siklus I

\begin{tabular}{|c|c|c|c|c|}
\hline & \multicolumn{2}{|c|}{ Nilai rata-rata } & \multirow{2}{*}{$\begin{array}{l}\text { Nilai Rata- } \\
\text { rata }\end{array}$} & \multirow{2}{*}{ Kategori } \\
\hline & Pertemuan 1 & Pertemuan 2 & & \\
\hline Siklus I & 50 & 65 & 58 & Kurang \\
\hline Siklus II & 66 & 78 & 72 & Cukup \\
\hline
\end{tabular}

Nilai aktivitas siswa tiap indikator

\begin{tabular}{llcccc}
\hline \multirow{2}{*}{ No } & \multicolumn{1}{c}{ Aspek yang diamati } & \multicolumn{2}{c}{ Nilai Rata-rata } & \multicolumn{2}{c}{$\begin{array}{c}\text { Nilai Rata-rata } \\
\text { (\%) }\end{array}$} \\
\cline { 3 - 6 } & \multicolumn{2}{c}{ Siklus I } & Siklus II & Siklus I & Siklus II \\
\hline 1. & $\begin{array}{l}\text { Antusias peserta didik dalam } \\
\text { mengikuti pembelajaran }\end{array}$ & 3,35 & 3,85 & $83,75 \%$ & $96,25 \%$ \\
2. & $\begin{array}{l}\text { Interaksi siswa dengan guru } \\
\text { 3. }\end{array}$ & 1,80 & 3,15 & $45,00 \%$ & $78,75 \%$ \\
& Interaksi antar peserta didik & 2,70 & 3,20 & $67,25 \%$ & $80,00 \%$ \\
4. & Kerjasama kelompok & 3,05 & 3,75 & $76,25 \%$ & $93,75 \%$ \\
5. & $\begin{array}{l}\text { Aktifitas Peserta didik dalam } \\
\text { diskusi kelas. }\end{array}$ & 1,65 & 3,25 & $41,25 \%$ & $81,25 \%$ \\
6. & $\begin{array}{l}\text { Partisipasi Peserta didik dalam } \\
\text { menyimpulkan hasil pembahasan. } \\
\text { Nilai rata-rata }\end{array}$ & 1,30 & 2,4 & $32,50 \%$ & $60,00 \%$ \\
\hline
\end{tabular}

Hasil perhitungan persentase observasi keterlaksanaan model

\begin{tabular}{cccc}
\hline Siklus & \multicolumn{2}{c}{ Total Skor } & \multirow{2}{*}{$\begin{array}{c}\text { Persentase } \\
\text { keterlaksanaan (\%) }\end{array}$} \\
\cline { 2 - 3 } & Ya & Tidak & \\
\hline I & 150 & 12 & $\mathbf{9 2 , 6}$ \\
II & 156 & 6 & $\mathbf{9 6 , 3}$ \\
\hline
\end{tabular}

Penerapan Model Flipped Classroom dan Course Review Horray Berbasis Lesson Study untuk Meningkatkan Aktivitas dan Hasil Belajas Siswa Kelas XI IPS 2 MAN Kota Batu Tahun Ajaran 2016/2017

Penerapan model pembelajaran flipped classroom dan course review horray berbasis lesson study, diterapkan pada setiap siklus di seluruh pertemuan. Selama pembelajaran berlangsung pada siklus I dan II, penerapan model pembelajaran flipped classroom dan course review horray berbasis lesson study pada mata pelajaran ekonomi sudah berjalan dengan baik meskipun kurang sempurna pada siklus I. Pembelajaran sepenuhnya telah 
bergeser sesuai dengan instruksi model pembelajaran flipped class-room dan course review horray.

Berdasarkan konsep model pembelajaran Flipped Classroom yang telah disampaikan oleh adalah Bergmann and Sams (2012) bahwa ketika pembelajaran yang seperti biasa dilakukan di kelas dilakukan oleh siswa di rumah, dan pekerjaan rumah yang biasa di kerjakan di rumah diselesaikan di sekolah. Pada penelitian ini siswa telah mempelajari materi di rumah melalui video pembelajaran yang telah diberikan oleh guru sehari sebelum pembelajaran dimulai. Sedangkan tugas yang biasanya dikerjakan dirumah pada penelitian ini dikerjakan di kelas melalui kegiatan diskusi kelompok dan diskusi kelas. Pemahaman siswa mengenai materi yang telah dilakukan sebelum kelas dimulai sangat membantu siswa dalam memecahkan permasalahan yang diberikan oleh guru di dalam kelas. Siswa lebih aktif menghubungkan persoalan yang diberikan guru dengan materi yang sudah disaksikan sebelumnya. Dalam hal ini peran video pembelajaran sebagai priming sangatlah terlihat. Sejalan dengan yang disampaikan oleh Bodie et al., (2006) efek priming pada memori menunjukkan bahwa ketika siswa mendapat rangsangan tertentu, misalnya satu fakta, memori atau ingatan mereka akan menguhubungkan pengalaman mereka sebelumnya (priming) yang berhubungan dengan rangsangan.

Kegiatan didalam kelas sepenuhnya diisi dengan kegiatan diskusi yang menuntut partisipasi siswa dalam membentuk pengetahuan yang sempurna, maka keberadaan guru didalam kelas hanya sebagai fasilitator. Hal tersebut sesuai dengan The Flipped Learning Network \& Pearson's School Achievement Services dalam Hamdan dan Mc. Knight (2013) bahwa salah satu pilar utama model pembelajaran flipped classroom adalah model pembelajaran yang berpusat pada guru berganti menjadi berpusat pada siswa, sehingga siswa lebih aktif terlibat dalam pembentukan pengetahuannya.

Selama proses kegiatan pembelajaran didalam kelas siswa menghabiskan sebagian besar waktu pembelajaran dengan berinteraksi satu sama lain dalam kegiatan diskusi baik diskusi kelompok maupun diskusi kelas. Hal ini sesuai dengan teori yang disampaikan oleh Johnson (2013) Flipped classroom merupakan strategi yang dapat diberikan oleh pendidik dengan cara meminimalkan jumlah instruksi langsung dalam praktek mengajar mereka sambil memaksimalkan interaksi satu sama lain.

Memberikan pertanyaan yang dikemas dalam bentuk permainan course review horray sangat efektif dalam membangun semangat belajar dan aktivitas siswa. Selama permainan ini berlangsung siswa menunjukkan respon yang baik, antar kelompok sangat antusias dalam menjawab setiap pertanyaan. Sesuai dengan pernyataan Shoimin (2014: p. 55), model pembelajaran course review horay memiliki kelebihan yaitu siswa akan terlatih melakukan kerjasama untuk menjawab pertanyaan pada saat guru memberikan soal secara acak untuk membentuk tanda checklist (v) secara horisontal, vertikal atau diagonal. Selain itu pemberian penjelasan pada masing-masing soal mampu menjadi penguatan bagi pemahaman siswa.

Kegiatan lesson study selama penerapan berlangsung sangat membantu dalam penelitian ini guna meningkatkan aktivitas dan hasil belajar siswa. Temuan kejadian yang dialami siswa pada setiap pertemuan mampu membantu peneliti melakukan perbaikan pada cara mengajar guru pada pertemuan selanjutnya sehingga kualitas pembelajaran menjadi lebih baik. Sesuai dengan pernyataan dari tim pengembang PPL Universitas Negeri Malang (2011) bahwa Lesson study merupakan suatu pendekatan peningkatan kualitas pembelajaran yang dilaksanakan oleh guru secara kolaboratif. Dalam penelitian ini setiap tahapan dilakukan bersama dengan seluruh tim lesson study yang terdiri dari peneliti, guru pamong dan 2 teman sebaya. 


\section{Aktivitas Siswa Pada Mata Pelajaran Ekonomi yang Menerapkan Model Flipped Calssroom dan Course Review Horray Berbasis Lesson Study}

Penerapan model pembela-jaran flipped classroom dan course review horray berbasis lesson study adalah bertujuan untuk meningkatkan aktivitas belajar siswa. Penelitian ini mengamati aktivitas belajar siswa yang termasuk dalam hasil belajar ranah afektif melalui interaksi siswa dengan siswa dan interaksi siswa dengan guru. Berdasarkan petunjuk teknis penilaian afektif di SMA (http://Juknispenilaianafektif.pdf) yang diterbitkan oleh Departemen Pembinaan Pendidikan SMA terdapat beberapa indikator dalam mengamati aktivitas siswa, diantaranya adalah: 1) Antusias peserta didik dalam mengikuti pembelajaran; 2) Interaksi siswa dengan guru; 3) Interaksi antar peserta didik; 4) Kerjasama kelompok; 5) Aktivitas peserta didik dalam kelompok; 6) Partisipasi peserta didik dalam menyimpulkan hasil pembahasan. Pada indikator ke-5 peneliti mengubah menjadi aktivitas peserta didik dalam diskusi kelas karena dalam penelitian ini pembelajaran terdiri dari dua jenis diskusi yaitu diskusi kelompok dandiskusi kelas. Setiap indikator peneliti membuat rincian penjelasan 4 aktivitas siswa yang dilakukan didalam kelas. Berdasarkan pengamatan yang dilakukan oleh observer selama proses pembelajaran berlangsung terdapat peningkatan aktivitas belajar siswa dari siklus I ke siklus II. Berikut ini uraiannya:

\section{Antusias peserta didik dalam mengikuti pembelajaran}

Pada indikator ini terdapat 4 penjelasan aktivitas siswa, yaitu peserta didik memperhatikan penjelasan guru, peserta didik tidak mengerjakan pekerjaan lain, peserta didik spontan bekerja apabila diberi tugas, dan peserta didik tidak terpengaruh situasi di luar kelas. Pada kedua siklus indikator ini menunjukkan persentase keberhasilan yang baik. Pada siklus II nilai rata-rata pada indikator ini mengalami peningkatan. Menurut hasil observasi, keseluruhan aktivitas ditampilkan oleh hampir seluruh siswa. Sebagian besar siswa antusias dalam mengikuti pembelajaran ekonomi yang menggunakan model pembelajaran flipped classroom dan course review horray berbasis lesson study ini. Hal ini terlihat dari bagaimana siswa memperhatikan penjelasan guru, disiplin dan respon peserta didik dalam mengerjakan tugas yang diberikan guru yang baik serta peserta didik yang sebegian besar tidak terpegaruh situasi diluar kelas sehingga fokus dalam pembelajaran.

\section{Interaksi siswa dengan guru}

Aktivitas-aktivitas pada indi-kator ini diantaranya peserta didik bertanya kepada guru, peserta didik menjawab pertanyaan guru, peserta didik memanfaatkan guru sebagai narasumber, peserta didik meman-faatkan guru sebagai fasilitator. Pada siklus I siswa kurang memanfaatkan keberadaan guru sebagai narasumber dan fasilitator. Interaksi siswa dan guru hanya terlihat saat guru memberikan pertanyaan tetapi hanya siswa tertentu yang mendominasi dalam menjawab pertanyaan tersebut. Hanya beberapa siswa yang berani memanfaatkan keberadaan guru baik dalam diskusi kelompok maupun diskusi kelas. Berdasarkan hasil observasi pada siklus I nilai rata-rata indikator ini hanya sangat rendah namun pada siklus II sudah mulai mengalami peningkatan yang sithegnifikan. Banyak siswa yang yang sudah tidak canggung lagi untuk berkomunikasi dengan guru. Usaha guru meyakinkan jika jawaban siswa salah tidak akan mengurangi nilai. Dorongan guru tersebut membuat siswa tetap termotivasi untuk aktif dalam kegiatan belajar.

\section{Interaksi antar peserta didik}

Pada siklus I dan II indikator interaksi antar peserta didik terdiri dari aktivitas diantaranya peserta didik bertanya kepada teman dalam satu kelompok, peserta didik 
menjawab pertanyaan teman dalam satu kelompok, peserta didik bertanya kepada teman dalam kelompok lain, peserta didik menjawab pertanyaan teman dalam kelompok lain menunjukkan hasil yang baik. Berdasarkan hasil observasi nilai rata-rata indikator ini pada siklus I dan siklus II adalah stabil. Hal ini dikarenakan siswa sangat leluasa saat berinteraksi dengan temannya, sehingga interaksi antar peserta didik baik dalam diskusi kelompok maupun diskusi kelas tercipta dengan baik. Siswa terlihat memanfaatkan dengan baik anggota kelompoknya dengan bertanya dan menjawab pertanyaan teman sesama kelompoknya. Selain itu siswa juga sesekali bertanya kepada siswa dari kelompok lain yang duduk didekatnya. Hal ini menunjukkan bahwa siswa belajar tidak hanya melalui guru melainkan teman sebaya juga dapat dijadikan sumber belajar.

\section{Kerjasama kelompok}

Indikator kerjasama kelompok terdiri dari 4 aktivitas diantaranya peserta didik membantu teman dalam kelompok yang menjumpai masalah, peserta didik meminta bantuan kepada teman, jika mengalami masalah, peserta didik mencocokkan jawaban/konsepsinya dalam satu kelompok dan adanya pembagian tugas dalam kelompok. Pada siklus I dan siklus II menururt hasil pengamatan oleh observer aktivitas-aktivitas pada indikator ini terlihat cukup banyak ditampilkan siswa. Hal ini seperti halnya interaksi antar peserta didik, siswa cenderung lebih aktif saat berinteraksi dengan siswa yang lainnya. Diskusi kelompok berjalan dengan baik karena adanya pembagian tugas dan seluruh anggota kelompok terlihat saling menghargai pendapat anggota dalam kelompok.

\section{Aktivitas peserta didik dalam diskusi kelas}

Berdasarkan pengamatan para observer pada siklus I indikator yang terdiri dari aktivitas peserta didik mengemukakan pendapatnya, peserta didik menanggapi pertanyaan/ pendapat teman sejawat, peserta didik mengerjakan tugas kelompok dan peserta didik menjelaskan pendapat/ pekerjaannya sangat rendah. Hal ini dikarenakan banyak siswa yang malu untuk berbicara yang kemudian didengarkan oleh seluruh siswa dikelas. Siswasiswa tersebut meminta teman satu kelompoknya untuk menyampaikan pendapatnya. Sehingga diskusi kelas hanya didominasi oleh siswa-siswa tertentu. Namun karena dorongan dan stimulus yang diberikan guru siswa-siswa yang malu tersebut berani menyampaikan pendapatnya. Sehingga selama pengamatan aktivitas belajar siswa dalam diskusi kelas pada sisklus II, observer menemukan peningkatan yang cukup signifikan hal ini ditunjukkan pada persentase yang meningkat. Sebagian besar siswa aktif menyampaikan pendapatnya dalam kegiatan diskusi kelas. Tetapi guru tetap harus memberi motivasi dan stimulus yang menarik bagi siswa agar tertarik berbicara didalam diskusi kelas.

\section{Partisipasi peserta didik dalam menyimpulkan hasil pembahasan}

Pada siklus I, berdasarkan pengamatan yang dilakukan oleh para observer indikator yang terdiri dari aktivitas peserta didik mengacungkan tangan untuk ikut menyimpulkan, peserta didik merespon pernyataan/ simpulan temannya, peserta didik menyempurnakan simpulan yang dikemukakan oleh temannya dan peserta didik menghargai pendapat temannya ini cukup rendah. Hal ini karena pada siklus I manajemen waktu yang dilakukan oleh guru kurang baik, sehingga pada tahap akhir pembelajaran waktu yang tersisa hanya beberapa menit. Maka penyusunan kesimpulan hanya dilakukan oleh guru bersama 1 siswa. Kekurangan ini yang membuat aktivitas pada indikator ini tidak banyak ditampilkan siswa. 
Pada siklus II, guru melakukan banyak perbaikan dalam manajemen waktu pembelajaran. Seluruh tahapan pembelajaran berjalan sesuai dengan alokasi waktu yang telah direncanakan dalam RPP. Hingga tahap penutupan waktu yang tersisa sesuai dengan perencanaan. Berdasarkan hasil observasi, aktivitas pada indikator ini banyak ditampilkan siswa, sehingga persentase pada indikator ini meningkat.

Berdasarkan uraian tersebut penerapan model pembelajaran flipped classroom dan course review horray berbasis lesson study mampu membuat siswa menampilkan barbagai aktivitas baik dalam berinteraksi dengan teman maupun guru. Aktivitas-aktivitas yang ditampilkan tersebut menunjukkan bahwa terjadi peningkatkan aktivitas siswa didalam kelas. Hal ini sesuai dengan penelitian yang telah dilakukan oleh Eunice Oyitayo Olakanmi pada tahun 2016 yang berjudul The Effects of Flipped Classroom Model of Intruction on Students; performance and Attitudes Forwards Chemistry. Pada penelitian tersebut penerapan model pembelajaran flipped classroom mampu meningkatkan penampilan siswa (Student performance). Pada Kelas eksperimen sebesar 10,82 dari nilai maksimal 15 sedangkan kelas kontrol memperoleh nilai $M$ sebesar 7,21. Sejalan dengan penelitian tersebut, penelitian lain yang dilakukan oleh Aksarina Shanti pada tahun 2013 mengenai penerapan model pembelajaran course review horray pada mata pelajaran geografi siswa kelas X-5 SMA Negeri 1 Batu juga mampu meningkatkan aktivitas dan hasil belajar siswa.

\section{Hasil Belajar Siswa Pada Mata Pelajaran Ekonomi yang Menerapkan Penerapan Model Flipped Classroom dan Course Review Horray Berbasis Lesson Study}

Hasil belajar pada penelitian ini merupakan sebuah pencapaian dari proses pembelajaran yang telah dilaksanakan dengan mengerjakan tes yang diberikan oleh guru. Sesuai dengan teori yang disampaikan oleh Sudjana (2014) menyatakan bahwa hasil belajar merupakan kemampuan yang dimiliki oleh siswa setelah ia menerima pengalaman belajarnya. Hasil belajar tergantung dari individu yang bersangkutan. Kondisi dimana sesorang siswa memaksimalkan proses belajarnya, maka hasil belajarpun juga baik. Begitu juga sebaliknya, ketika seorang siswa kurang bersemangat dalam berkompetisi dengan temannya untuk menjadi yang terbaik maka hasil belajarnyapun juga kurang baik. Disini diperlukan pengawasan dari peneliti akan hasil belajar siswa.

Penelitian yang dilakukan oleh Dwi Irawati (2013) setelah menerapkan model pembelajaran course review horray menunjukkan bahwa pada hasil belajar aspek kognitif bahwa mulai dari siklus I sudah ada beberapa siswa yang nilai tes akhir siklusnya diatas KKM. Pada siklus II ketuntasan belajar klasikal telah tercapai saat dterapkan pada mata pelajaran Sejarah kelas XI di SMA Negeri I Ponggok. Selain itu penelitian dari Jalal Nouri (2016) bahwa low achiever mampu mengalami peningkatan hasil belajar yang signifikan serta penelitian dari Gross David (2015) bahwa hasil belajar siswa mengalami peningkatan sebesar $11,6 \%$.

Pada penelitian ini hasil belajar kognitif digunakan sebagai acuan yang menunjukkan seberapa besar tingkat pemahaman siswa dan penguasaan atau ingatan, pema-haman, aplikasi, analisis, sintesis dan evaluasi ketika menerapkan model pembelajaran flipped classroom dan course review horray berbasis lesson study berlangsung. Hasil belajar siswa dilihat dari perolehan nilai kelompok dan nilai tes yang dilakukan diakhir siklus penelitian. Berdasarkan analisis data hasil belajar siswa yang telah dilakukan oleh peneliti baik siklus I dan siklus II, penerapan model pembelajaran flipped classroom dan course review horray berbasis lesson study berhasil menngkatkan hasil belajar siswa jika dibandingkan dengan model pembelajaran sebelumnya.

Pada siklus I penerapan model pembelajaran flipped classroom dan course review horray berbasis lesson study hasil perhitungan persentase ketuntasan hasil belajar siswa 
pada aspek kognitif sedikit mengalami peningkatan jika dibandingkan dengan hasil belajar aspkek kognitif siswa pada pembelajaran sebelumnya. Pada siklus II dalam aspek kognitif menunjukkan adanya peningkatan presentase ketuntasan hasil belajar siswa yang cukup signifikan.

Berdasarkan peningkatan perolehan tersebut siswa telah menunjukkan perubahan atas kegiatan pembelajaran yang dilakukannya. Perubahan tersebut merupakan wujud dari nilai tambah pada kemampuan yang dimiliki siswa. Sesuai dengan yang disampaikan oleh Wayne \& Youngs (2003) bahwa hasil belajar berkaitan dengan value-added atau nilai tambah yang dimiliki siswa dari sebelum melakukan pembelajaran hingga setelah melakukan pembelajaran

Peningkatan hasil belajar disebabkan oleh banyak faktor, terutama kualitas pengajaran dan lingkungan belajar siswa. Penggunaan video pembelajaran yang sangat efektif dalam memberikan pengalaman belajar dan mempertajam ingatan siswa mengenai materi pembelajaran hal ini menunjukkan bahwa pengajaran lebih berkualitas.. Pemberian materi melalui video pembelajaran yang disaksikan siswa di rumah memberikan waktu yang panjang bagi guru dan siswa melakukan interaksi sehingga lingkungan atau kondisi belajar menjadi efektif. Seperti yang disebutkan oleh Caroll dalam Angkowo \& Kosasih (2007:p. 51) hal tersebut mampu memengaruhi hasil belajar siswa.

\section{KESIMPULAN}

Berdasarkan paparan data dan pembahasan yang telah dilakukan, maka dapat diperoleh kesimpulan bahwa penerapan model pembelajaran flipped calssroom dan course review horray berbasis lesson study pada mata pelajaran ekonomi kelas XI IPS 2 MAN Kota Batu tahun ajaran 2016/2017 terlaksana dengan sangat baik. Hal tersebut ditunjukkan pada persentase tingkat keterlaksanaan model pembelajaran siklus I sebesar $92,6 \%$ dan pada siklus II mengalami peningkatan sebesar 3,7\% menjadi 96,3\%. Selain itu penerapan model pembelajaran flipped calssroom dan course review horray berbasis lesson study pada mata pelajaran ekonomi kelas XI IPS 2 MAN Kota Batu dapat meningkatkan aktivitas belajar siswa. Hal ini dibuktikan dari nilai rata-rata aktivitas belajar siswa pada siklus I sebesar 58 dan meningkat pada siklus II menjadi 72. Penerapan model pembelajaran flipped calssroom dan course review horray berbasis lesson study pada mata pelajaran ekonomi kelas XI IPS 2 MAN Kota Batu juga dapat meningkatkan hasil belajar siswa. Hal ini dapat dilihat dari persentase ketuntasan belajar siswa pada siklus I sebesar $75 \%$ yang kemudian meningkat menjadi $89,29 \%$ pada siklus II.

\section{DAFTAR RUJUKAN}

Angkowo, R \& Kosasih, A (2007) Optimalisasi Media Pembelajaran. Jakarta: PT. Garsindo

Bergmann, J. \& Sams, A. (2012) Flip Your Classroom Reach Every Student In Every Class Every Day. United Stated of America: ISTE

Bodie et al. (2006) Chunking, Priming, and Active Learning: Toward an innovative and blended approach to teaching communication-related skills. Interactive Learning Environments, 14 (2). (Online)

(http://www.tandfonline.com/action/doSearch?AllField=chunking+prim ing+and+active+learning), diakses 20 September 2016

Burke, Alison (2011) Group Work: How to Use Groups Effectivity. The Journal of Effective Teaching, 11 (2). (Online), 
(http://www.uncw.edu/jet/articles/Vol11_2/Burke.html), diakses 9 September 2016 Direktorat Pembinaan SMA (2010) Teknik Penyusunan Perangkat Penilaian Afektif di SMA.(Online),(http://regulasi.sman1jember.sch.id/PeraturanPemerintah\%\&Menteri /PetunjukTeknisdanPedoman/JuknisPenilaianAfektif-ISI-Revisi.pdf).diakses pada tanggal 27 Oktober

Gómez, E.S., Núñez, M.J.S., Gómez, A.I.P. \& Trapero, N.P (2015) Lesson study and the development of teacher's competences: From practical knowledge to practical thinking", International Journal for Lesson and Learning Studies. 4 (3). (Online), (http://emeraldinsight.com/doi/abs/10.1108/IJLLS-09-2014-0034), diakses 9 September 2016

Gross, David (2015) Increased Preclass Preparation Underlies Student Outcome Improvement in the Flipped Classroom (Online). (http://www.lifescied.org /content/14/4/ar36.full). Diakses 5 November 2016

Hamdan, Noora., McKnight, Patrick., McKnight, Kathrine. \& Arfstrom, Kari M (2013) A White Paper Based On The Literature Review Titled: Review Of Flipped Learning. London: Pearson.

Irawati, Dwi. (2013) Penerapan Model Pembelajaran Course Review Horray Terhadap Hasil Belajar Sejarah Siswa di SMA Negeri 1 Ponggok. Skripsi. Malang: Universitas Negeri Malang

Johnson, Graham Brent. (2013) Student Perceptions Of The Flipped Classroom. Tesis. Okanagan: Educational Technology The University Of British Columbia.

Nouri, Jalal (2016). The Flipped Classroom: For Active, Effective and Increase LearningEspeciallyforLow

Achiever.(Online),(http://link.springer.com/article/10.1186/s41239-016-0032-z).

Diakses 02 November 2016

Olakanmi, Eunice Oyitayo. (2016.)The Effect of Flipped Classroom Model of Instruction on Students Performance and Attitudes Forwards Chemistry (Online), (http://link.springer.com/article/10.1007/s10956-016-9657-x).

Diakses 02 November 2016

Shanti, Aksarina. (2013) Penerapan Model Pembelajaran Course Review Horray untuk Meningkatkan Aktivitas dan Hasil Belajar Geografi Siswa Kelas X-5 SMA Negeri 1 Batu. Skripsi. Malang: Universitas Negeri Malang

Shimamoto,Dean (2012) The Implementing a Flipped Classroom:An Instuctional Module.Makalah yang diseminarkan pada Technology,College,and Community (TCC) Worldwide Online Conference,17 April 2012.(Online), (http://scholarspace.manoa.hawaii.edu/handle/10125/22527),diakses 4 September 2016

Slameto. (2003) Belajar dan Faktor-faktor yang Mempengaruhinya. Jakarta: Rineka Cipta

Shoimin, Aris. (2014) 68 Model Pembelajaran Inovatif dalam Kurikulum 2013. Yogyakarta: Ar-Ruzz Media

Sudjana, Nana. (2014) Penilaian Hasil Proses Belajar Mengajar. Bandung:PT.RemajaRosdikarya

Tim Pengembang PPL UM. (2011) Petunjuk Teknis Pelaksanaan Lesson Study Universitas Negeri Malang. Malang: Unit Pelaksana Teknis Paraktik Pengalaman Lapangan (UPT-PPL) UM

Wayne, J Andrew and Youngs, Peter. (2003) Teacher Characteristics and Student Achievement Gains: A Review. American Educational Reasearch Association, 73 (1). (Online) (http://journals.sagepub.com/doi/pdf/10.3102/00346543073001089). Diakses tanggal 3 September 2016 